\title{
IMPLEMENTASI PENINGKATAN KOGNITIF LANSIA MELALUI MEMORY TRAINING
}

\author{
Icca Narayani Pramudaningsih ${ }^{1}$, Ambarwati ${ }^{2}$ \\ ${ }^{1,2}$ Akademi Keperawatan Krida Husada \\ Email: iccanarayani14@gmail.com
}

\begin{abstract}
ABSTRAK
Implementasi untuk meningkatkan fungsi kognitif (memori) lansia dengan memberikan tindakan keperawatan untuk mencapai hasil kesehatan dan peningkatan kualitas hidup lansia. Tindakan yang dilakukan dengan memory training. Memory training merupakan implementasi dalam meningkatkan kemampuan memory dengan teknik mnemonic, Tehnik Mnemonic ini membantu kinerja dari memory (ingatan) yang dapat dioptimalkan dengan latihan. Materi yang digunakan di dalam memory training yaitu tentang orietasi waktu dan menghafal 9 kata dengan cepat (re call). Desain pada penelitian ini Quasy Experimental dengan rancangan Pretest Post test Control Group Design. Instrumen nya digunakan dalam pre test dan post test dengan MiniCog dan clock drawing test (CDT), Sedangkan intervensi dalam memory Training dengan menggunakan instrumen mnemonic. Sampel dalam penelitian ini 30 lansia yang usia 60 tahun atau lebih, mampu berkomunikasi dengan baik, lansia yang tidak mengalami gangguan aktivitas dan bersedia menjadi responden, yang di bagi 2 kelompok, 15 lansia kelompok intervensi dan 15 lansia kelompok kontrol. Analisa efektivitas peningkatan kognitif lansia melalui memory training dengan uji statistik Wilcoxon signed ranks test dengan program SPSS 25.0 dengan tingkat kemaknaan $\mathrm{p} \leq 0,05$. Hasil uji Wilcoxon menunjukkan nilai Recall Test pada kelompok intervensi $\mathrm{p}$ value 0.001 atau $\mathrm{p} \leq 0.05$ yang berarti $\mathrm{H} 1$ diterima yaitu terdapat perbedaan sebelum dan sesudah diberikan Tindakan memory training. Penilaian Clock Drawinng test pada kelompok intervensi dengan nilai $\mathrm{p}$ value 0.003 atau $\mathrm{p} \leq 0.05$ yang berarti $\mathrm{H} 1$ diterima yaitu adanya perbedaan sebelum dan sesudah diberikannya Tindakan memory training.
\end{abstract}

Kata Kunci: Kognitif, Lansia, Memory training.

\begin{abstract}
Implementation for increase cognitive function ( memory) elderly by giving the act of nursing to achieve a result health and wellbeing of elderly. The act of performed with memory training .Memory training is the implementation improve the ability to technique mnemonic memory, technique mnemonic it helps the performance of memory ( memory) that can be optimized by the exercise. Matter used in memory training which was about orietasi time and memorization 9 said quickly (re call). A design on this research quasy experimental, pretest post test control group design. An instrument his used in pre test and post test with minicog and clock drawing test ( CDT ), while intervening in memory training with use of the instruments mnemonic. Sample in this research 30 elderly whose age 60 years or more, able to communicate well, elderly did not experience disorder activity and willing to become respondents, who in for 2 groups, 15 elderly group intervention and 15 elderly the control group. Effectiveness cognitive analysis increase elderly through training memory with statistical tests wilcoxon test the SPSS 25.0 with the $p \leq 0.05$. The shows the wilcoxon recall test in the value or on $p$ intervention $0.001 p \leq 0.05$
\end{abstract}


meaning hl received the differences before and after given the act of memory training Clock assessment drawinng test in the intervention the value or on $p 0.003 p \leq 0.05$ meaning $H 1$ received the differences in her memory before and after the act of training.

Keywords: Cognitif, elderly, Memory training 


\section{LATAR BELAKANG}

Lanjut Usia adalah tahapan tumbuh kembang yang berlangsung secara terus menerus yang dimulai sejak lahir (Triwibowo, H. dan Puspitasari, K., 2018). Lansia sekarang menjadi perhatian masalah global karena semakin bertambahnya jumlah populasi lansia di dunia. jumlah lansia diperkirakan mencapai angka 500 juta dengan usia rata-rata 60 tahun dan diperkirakan pada tahun 2025 akan mencapai 1,2 milyar (US Cencus Bureau. 2018). Pertambahan jumlah lansia di Indonesia dalam kurun waktu tahun 1990 sampai 2025, tergolong tercepat di dunia (US Cencus Bureau, 2018). Data Badan Pusat Statistik (BPS) menunjukan bahwa penduduk lansia pada tahun 2000 berjumlah 14,4 juta jiwa $(7,18 \%)$. Pada tahun 2010 diperkirakan menjadi 23,9 juta jiwa (9,77\%) dan pada tahun 2020 akan berjumlah 28,8 juta jiwa $(11,34 \%)$ (Badan Pusat Statistik, 2010).

Akibat populasi usia lanjut yang meningkat maka akan terjadi transisi epidemiologi yaitu bergesernya pola penyakit dari penyakit infeksi dan gangguan gizi menjadi penyakitpenyakit degeneratif, diabetes, hipertensi, neoplasma, dan penyakit jantung koroner (Ogawa, Masayo, et al. 2018). Konsekuensi dari peningkatan warga usia lanjut adalah meningkatnya jumlah pasien lansia dengan kerakteristiknya yang berbeda dengan warga pada usia yang berbeda (Ogawa, Masayo, et al. 2018). . Penyakit degenertif lansia terdiri dari beberapa jenisnya, salah satu yang banyak terjadi adalah kerusakan pada saraf otak yang biasa disebut dengan penurunan kognitif. Penurunan kognitif pada lansia apabila tidak ditangani akan memyebabkan penurunan ingatan pada lansia (Abraham, C \& Shanley, E 1997). Hal ini sesuai dengan teori kemunduran yang menyatakan dengan bertambahnya usia, daya ingat akan mengalami penurunan. Perubahan neuron dan sinaps otak sebagai pembentukan ingatan juga mengalami penurunan seiring bertambahnya usia (Solso, RL, Maclin, OH \& Maclin, MK, 2008). Akibat lainnya yaitu informasi yang tidak cepat dipindahkan ke ingatan jangka pendek akan menghilang (Solso, RL, Maclin, OH \& Maclin, MK, 2008). Akibat dari penurunan fungsi kognitif maka akan berdampak pada kehidupan lansia sehari-hari. Menurut penelitian yang dilakukan kepada penderita demensia dan penderita demensia dengan penyakit diabetes, didapatkan hasil bahwa dampak gangguan kognitif demensia bagi kehidupan mereka adalah kurangnya kepercayaan diri, malu, dan khawatir dengan perubahan peran dimana penderita tidak bisa mandiri dan masih butuh bantuan orang lain untuk melakukan aktivitas seharihari (Santoso et al, 2018). Untuk itu, perlu dilakukan upaya untuk mempertahankan fungsi kognitif pada lansia. Upaya yang dapat dilakukan untuk mempertahankan fungsi kognitif yaitu dengan cara meningkatkan aktivitas yang bisa menstimulasi otak (Santoso et al, 2018). . Berdasarkan penelitian yang dilakukan oleh Turana (2014) tentang hubungan antara kemampuan kognitif dan aktivitas santai (bermain catur, atau kartu) (Turana,2014). Ada beberapa faktor yang dapat mempengaruhi memori diantaranya ialah jenis kelamin, usia, latihan rutin fisik dan memori, stres dan depresi, kondisi fisik, dan kondisi lingkungan. Suatu penelitian menunjukkan adanya hubungan positif antara usia dan penurunan fungsi kognitif yakni terjadinya penurunan $16 \%$ pada kelompok umur $65-69,21 \%$ pada $70-74,30 \%$ pada $75-79$, dan $44 \%$ pada 80 tahun (Santoso et al, 2018). .

Implementasi untuk meningkatkan fungsi kognitif (memori) lansia dengan memberikan tindakan keperawatan untuk mencapai hasil kesehatan dan peningkatan kualitas hidup lansia. Tindakan yang dilakukan melalui tindakan farmakologi dan non farmakologi yaitu dengan memory training. Memory training merupakan implementasi dalam meningkatkan kemampuan memory dengan teknik mnemonic. Tehnik Mnemonic yaitu suatu tehnik yang dipelajari yang mempunyai tujuan dalam membantu kinerja dari memory (ingatan) yang dapat dioptimalkan dengan latihan. Materi yang dapat digunakan didalam memory training yaitu tentang orietasi waktu dan menghafal 9 kata dengan cepat (re call) (Acevedo, A, Loewenstein, D, A.2007). Tindakan non farmakologi ini berupa latihan atau permainan yang prosedurnya membutuhkan konsentrasi atau atensi, orientasi (tempat, waktu, dan situasi) dan memori. 
Manfaat adanya program stimulasi otak ini tidak hanya menurunkan proses kemunduran otak lansia tetapi juga menjadikan lansia mampu berperan aktif dan produktif dalam menjalankan aktivitasnya. Berdasarkan latar belakang diatas penulis tertarik mengambil judul penelitian "Implementasi Peningkatan kognitif Lansia melalui Memory Training”:

\section{METODE PENELITIAN}

Desain pada penelitian adalah Quasy Experimental dengan rancangan Pretest Post test Control Group Design, jenis penelitian yang bertujuan untuk menentukan pengaruh dari suatu tindakan pada kelompok subjek yang mendapat perlakuan, kemudian dibandingkan dengan kelompok subjek yang tidak mendapat perlakuan (Sugiyono. 2010). Instrumen nya digunakan dalam pre test dan post test dengan MiniCog dan clock drawing test (CDT). Sedangkan intervensi dalam memory Training dengan menggunakan instrumen mnemonic. Sampel dalam penelitian ini adalah yang memenuhi karakteristik inklusi yaitu lansia usia 60 tahun atau lebih, mampu berkomunikasi dengan baik, lansia yang tidak mengalami gangguan aktivitas dan bersedia menjadi responden. total sampel penelitian yang memenuhi kriteria 30 lansia. Kemudian dari Lansia tersebut dibagi menjadi dua kelompok yaitu 15 sebagai kelompok eksperimen dan 15 responden sebagai kelompok kontrol. Analisa data numerik, data yang telah selesai dikumpulkan disajikan dalam bentuk distribusi frekuensi dan grafik. Untuk data numerik ini digunakan nilai mean, median, modus, standard deviasi dan inter quartil range (minimal dan maksimal) dari tiap variabel. Analisa bivariat dalam penelitian ini digunakan untuk menganalisa efektivitas peningkatan kognitif lansia melalui memory training. Selanjutnya data tersebut diolah dan diuji dengan menggunakan uji statistik Wilcoxon signed ranks test dengan program SPSS 25.0 dengan tingkat kemaknaan $\mathrm{p} \leq 0,05$ (Dahlan, Muhamad Sopiyudin, 2011).

\section{HASIL DAN PEMBAHASAN \\ Karakteristik Responden}

Subyek dalam penelitian ini adalah lansia yang berada di RPSLU Margo Mukti Rembang. Berdasarkan hasil penelitian diketahui beberapa karakteristik responden penelitian ini, antara lain karakteristik responden berdasarkan usia, jenis kelamin, dan Pendidikan.

\section{Distribusi Frekuensi Responden berdasarkan Usia Kelompok Intervensi}

Berikut adalah tabel distribusi frekuensi responden berdasarkan usia pada kelompok intervensi:

Tabel 1. Distribusi Frekuensi Responden berdasarkan Usia

\begin{tabular}{llll}
\hline No. & Umur & Frekuensi & Persentase (\%) \\
\hline 1. & $60-74$ & 13 & 87 \\
2. & $75-90$ & 2 & 13 \\
& Total & 15 & 100 \\
\hline
\end{tabular}

Berdasarkan tabel 1 distribusi frekuensi respoden berdasarkan usia pada kelompok intervensi, diketahui bahwa kelompok lanjut usia paling banyak berusia 60 - 74 tahun yaitu sebesar $87 \%$, disusul pada kelompok lanjut usia tua usia 75 - 90 tahun sebesar $13 \%$. 
2. Distribusi Frekuensi Responden berdasarkan Jenis Kelamin pada Kelompok Intervensi

Berikut adalah tabel distribusi frekuensi responden berdasarkan jenis kelamin pada kelompok intervensi :

Tabel 2 Distribusi Frekuensi Responden berdasarkan Jenis Kelamin

\begin{tabular}{llll}
\hline No. & Jenis Kelamin & Frekuensi & Persentase (\%) \\
\hline 1. & Laki-laki & 10 & 67 \\
2. & Perempuan & 5 & 33 \\
& Total & 15 & 100
\end{tabular}

Berdasarkan tabel 2 distribusi frekuensi respoden berdasarkan jenis kelamin pada kelompok intervensi, diketahui bahwa kelompok laki - laki mempunyai frekuensi yang paling banyak yaitu $67 \%$ dan untuk kelompok jenis kelamin perempuan sebesar 33\%.

3. Distribusi Frekuensi Responden berdasarkan Pendidikan pada Kelompok Intervensi Berikut adalah tabel distribusi frekuensi responden berdasarkan pendidikan pada kelompok intervensi:

Tabel 3 Distribusi Frekuensi Responden berdasarkan Pendidikan pada Kelompok Intervensi

\begin{tabular}{llcc}
\hline No. & Pendidikan & Frekuensi & Persentase (\%) \\
\hline 1. & SD & 10 & 67 \\
2. & SMP & 2 & 13 \\
3. & SMA & 3 & 20 \\
& Total & 30 & 100 \\
\hline
\end{tabular}

Berdasarkan tabel 3 distribusi frekuensi respoden berdasarkan Pendidikan pada kelompok intervensi, kelompok yang berpendidikan SD sebanyak 67\%, kelompok yang berpendidikan SMP sebanyak $13 \%$, dan yang berpendidikan SMA sebanyak $20 \%$.

4. Distribusi Frekuensi Responden berdasarkan Usia Kelompok Kontrol

Berikut adalah tabel distribusi frekuensi responden berdasarkan usia pada kelompok Kontrol :

Tabel 4. Distribusi Frekuensi Responden berdasarkan Usia

\begin{tabular}{llll}
\hline No. & Umur & Frekuensi & Persentase (\%) \\
\hline 1. & $60-74$ & 12 & 80 \\
2. & $75-90$ & 3 & 20 \\
& Total & 15 & 100 \\
\hline
\end{tabular}

Berdasarkan tabel 4 distribusi frekuensi respoden berdasarkan usia pada kelompok kontrol, diketahui bahwa kelompok lanjut usia yang berusia 60 - 74 yaitu 80\%, dan kelompok lanjut usia tua 75 - 90 sebanyak $20 \%$.

5. Distribusi Frekuensi Responden berdasarkan Jenis Kelamin pada Kelompok Kontrol

Berikut adalah tabel distribusi frekuensi responden berdasarkan jenis kelamin pada kelompok kontrol : 
Tabel 5 Distribusi Frekuensi Responden berdasarkan Jenis Kelamin

\begin{tabular}{llll}
\hline No. & Jenis Kelamin & Frekuensi & Persentase (\%) \\
\hline 1. & Laki-laki & 8 & 53 \\
2. & Perempuan & 7 & 47 \\
& Total & 15 & 100
\end{tabular}

Berdasarkan tabel distribusi frekuensi respoden berdasarkan jenis kelamin pada kelompok kontrol, diketahui bahwa kelompok laki - laki mempunyai frekuensi yang paling banyak yaitu $53 \%$ dan untuk kelompok jenis kelamin perempuan sebesar $47 \%$.

6. Distribusi Frekuensi Responden berdasarkan Pendidikan pada Kelompok Kontrol Berikut adalah tabel distribusi frekuensi responden berdasarkan pendidikan pada kelompok kontrol:

Tabel 6 Distribusi Frekuensi Responden berdasarkan Pendidikan pada Kelompok Kontrol

\begin{tabular}{llcc}
\hline No. & Pendidikan & Frekuensi & $\begin{array}{c}\text { Persentase } \\
(\boldsymbol{\%})\end{array}$ \\
\hline 1. & SD & 11 & 73 \\
2. & SMP & 4 & 27 \\
& Total & 15 & 100 \\
\hline
\end{tabular}

Berdasarkan tabel 6 distribusi frekuensi respoden berdasarkan Pendidikan pada kelompok kontrol, kelompok yang berpendidikan SD sebanyak 73\%, kelompok yang berpendidikan SMP sebanyak $27 \%$.

Distribusi penilaian Pre -Test dan Post - Test pada Kelompok Intervensi

Variabel utama yang di dalam penelitian ini adalah Peningkatan Kognitif pada lansia.

Berdasarkan hasil penelitian yang dilakukan, diperoleh hasil sebagai berikut:

1. Hasil Distribusi penilaian Pre -Test dan Post - Test pada Kelompok Intervensi

Tabel 7.Distribusi penilaian Pre tes dan Post test kelompok intervensi

\begin{tabular}{|c|c|c|c|c|c|c|}
\hline \multirow[t]{2}{*}{$\begin{array}{l}\text { Kode } \\
\text { Responden }\end{array}$} & \multicolumn{2}{|c|}{ Recall Test } & \multirow[t]{2}{*}{$\Delta$} & \multicolumn{2}{|c|}{$\begin{array}{l}\text { Clock } \\
\text { Drawing } \\
\text { test }\end{array}$} & \multirow[t]{2}{*}{$\Delta$} \\
\hline & Sebelum & Sesudah & & Sebelum & Sesudah & \\
\hline O1A & 4 & 6 & +2 & 4 & 3 & -1 \\
\hline $\mathrm{O} 2 \mathrm{~A}$ & 7 & 9 & +2 & 2 & 1 & -1 \\
\hline $\mathrm{O} 3 \mathrm{~A}$ & 7 & 9 & +2 & 1 & 1 & 0 \\
\hline $\mathrm{O} 4 \mathrm{~A}$ & 4 & 9 & +5 & 3 & 2 & -1 \\
\hline O5A & 4 & 5 & +1 & 3 & 2 & -1 \\
\hline O6A & 4 & 7 & +3 & 3 & 2 & 1 \\
\hline O7A & 9 & 9 & 0 & 1 & 1 & 0 \\
\hline O8A & 4 & 8 & +4 & 2 & 1 & -1 \\
\hline O9A & 8 & 9 & +1 & 1 & 1 & 0 \\
\hline O10A & 6 & 8 & +2 & 3 & 2 & -1 \\
\hline O11A & 4 & 8 & +1 & 3 & 2 & -1 \\
\hline $\mathrm{O} 12 \mathrm{~A}$ & 6 & 8 & +2 & 4 & 3 & -1 \\
\hline O13A & 4 & 8 & +4 & 3 & 2 & -1 \\
\hline O14A & 9 & 9 & 0 & 3 & 2 & -1 \\
\hline $\mathrm{O} 15 \mathrm{~A}$ & 7 & 9 & +2 & 2 & 1 & -1 \\
\hline Mean & 5.8 & 8.0 & 2.0 & 2.5 & 1.7 & 0.8 \\
\hline
\end{tabular}

Berdasarkan tabel 7 diketahui nilai rata - rata dari penilaian recall test kelompok intervensi pre test 5.8, dengan nilai maksimum 9 dan nilai minimum 4 dan nilai rata -rata penilaian recall test post test sebesar 8.0 dengan nilai maksimum 9 dan nilai minimum 5. Sedangkan penilaian clock drawing test kelompok intervensi pada pre test sebesar 2.5 dengan nilai maksimum 1 dan nilai minimum 3 dan untuk kelompok post test nilai rata -rata sebesar 1.7 dengan nilai maksimun 1 dan nilai minimum 4 . 
2. Hasil Distribusi penilaian Pre -Test dan Post - Test pada kelompok Kontrol

Tabel 8 Distribusi penilaian Pre tes dan Post test Kelompok Kontrol

\begin{tabular}{|c|c|c|c|c|c|c|}
\hline \multirow[t]{2}{*}{$\begin{array}{l}\text { Kode } \\
\text { Responden }\end{array}$} & \multicolumn{2}{|c|}{ Recall Test } & $\Delta$ & \multicolumn{2}{|c|}{$\begin{array}{l}\text { Clock } \\
\text { Drawing } \\
\text { test }\end{array}$} & \multirow[t]{2}{*}{$\Delta$} \\
\hline & Sebelum & Sesudah & & Sebelum & Sesudah & \\
\hline O1B & 4 & 4 & 0 & 4 & 4 & 0 \\
\hline $\mathrm{O} 2 \mathrm{~B}$ & 5 & 6 & -1 & 3 & 3 & 0 \\
\hline $\mathrm{O} 3 \mathrm{~B}$ & 7 & 7 & 0 & 2 & 2 & 0 \\
\hline $\mathrm{O} 4 \mathrm{~B}$ & 4 & 4 & 0 & 3 & 2 & -1 \\
\hline O5B & 4 & 4 & 0 & 3 & 3 & 0 \\
\hline O6B & 4 & 4 & 0 & 3 & 3 & -1 \\
\hline O7B & 4 & 4 & 0 & 4 & 4 & -1 \\
\hline O8B & 4 & 4 & 0 & 3 & 3 & 0 \\
\hline O9B & 4 & 4 & 0 & 2 & 2 & 0 \\
\hline O10B & 6 & 6 & 0 & 3 & 3 & 0 \\
\hline O11B & 4 & 4 & 0 & 3 & 3 & 0 \\
\hline O12B & 6 & 6 & 0 & 2 & 2 & 0 \\
\hline O13B & 4 & 4 & 0 & 3 & 3 & 0 \\
\hline O14B & 5 & 5 & 0 & 3 & 2 & -1 \\
\hline O15B & 8 & 8 & 0 & 2 & 2 & 0 \\
\hline Mean & 4.8 & 4.9 & 0 & 2.8 & 2.6 & -0.2 \\
\hline
\end{tabular}

Berdasarkan tabel 8 nilai rata - rata dari penilaian recall test kelompok kontrol pre test 4.8 dengan nilai maksimum 8 dan nilai minimum 4, nilai rata -rata penilaian recall test post test sebesar 4.9 dengan nilai maksimum 8 dan nilai minimum 4. Sedangkan penilaian clock drawing test kelompok kontrol pada pre test sebesar 2.8 dengan nilai maksimum 2 dan nilai minimum 4 dan mengalami penurunan nilai rata - rata post test yaitu 2.6 dengan nilai maksimum 2 dan nilai minimum 4.

\section{Hasil Uji Normalitas Data}

Analisis bivariat adalah melakukan uji normalitas data untuk masing-masing variabel penelitian. Hasil uji normalitas data dapat dilihat pada tabel berikut :

Tabel 9 Tabel Hasil Uji Normalitas Data

\begin{tabular}{lll}
\hline Variabel & P-Value & Keterangan \\
\hline $\begin{array}{l}\text { Skor Pre Test Recall Test } \\
\text { kelompok Intervensi }\end{array}$ & 0,006 & Distribusi Data Tidak Normal \\
$\begin{array}{l}\text { Skor Post test Recall Test } \\
\text { kelompok Intervensi }\end{array}$ & 0,001 & Distribusi Data Tidak Normal \\
$\begin{array}{l}\text { Skor Pre Test Clock Drawing } \\
\begin{array}{l}\text { Test kelompok control } \\
\text { Skor Post Test Clock Drawing }\end{array}\end{array}$ & 0,003 & Distribusi Data Tidak Normal \\
Test kelompok control & 0,029 & Distribusi Data Tidak Normal \\
\hline
\end{tabular}

Berdasarkan tabel 9 diketahui bahwa hasil uji normalitas data pada pre test Recall Test kelompok intervensi sebesar $\mathrm{p}=0.006$ dan post test $\mathrm{p}=0.001$. Sedangkan uji normalitas pada pre test Clock Drawing Test kelompok kontrol dengan nilai $\mathrm{p}=0.003$ dan untuk kelompok post test pada pre test clock drawing test kelompok kontrol $\mathrm{p}=0.029$. Dilihat dari keseluruhan data tersebut data pre test dan post test recall test kelompok intervensi maupun pre test dan post test Clock Drawing Test kelompk kontrol data tidak berdistribusi normal, atau nilai probabilitas (P-Value) kurang dari 0.05. Sehingga Analisa bivariat untuk melihat perbandingan nilai post test dan pre test antara kelompok intervensi maupun kelompok kontrol adalah denga uji Wilcoxon. 
Tabel 10 Hasil Uji Wilcoxon

\begin{tabular}{lll}
\hline Variabel & P-Value & Keterangan \\
\hline $\begin{array}{l}\text { Nilai Recall Test kelompok } \\
\text { intervensi }\end{array}$ & 0.001 & Ada perbedaan \\
$\begin{array}{l}\text { Nilai Clock Drawing Test pada } \\
\text { kelompok intervensi }\end{array}$ & 0.003 & Ada Perbedaan \\
$\begin{array}{l}\text { Nilai Recall Test kelompok } \\
\text { control }\end{array}$ & 0.317 & Tidak ada perbedaan \\
$\begin{array}{l}\text { Nilai Clock Drawing Test pada } \\
\text { kelompok control }\end{array}$ & 0.083 & Tidak ada perbedaan \\
\hline
\end{tabular}

Berdasarkan tabel 10 uji Wilcoxon didapatkan nilai Recall Test pada kelompok intervensi $\mathrm{p}=$ 0.001 atau $\mathrm{p} \leq 0.05$ yang berarti $\mathrm{H} 1$ diterima yaitu terdapat perbedaan sebelum dan sesudah diberikan Tindakan memory training. Penilaian Clock Drawinng test pada kelompok intervensi dengan nilai $\mathrm{p}=$ 0.003 atau $\mathrm{p} \leq 0.05$ yang berarti $\mathrm{H} 1$ diterima yaitu adanya perbedaan sebelum dan sesudah diberikannya Tindakan memory training. Uji Wilcoxon pada kelompok kontrol menunjukkan nilai Recall Test diperoleh nilai 0.317 dan pada Clock Drawing Test diperoleh nilai 0.083, data penilaian ini menunjukkan bahwa p >0.05 yang berarti bahwa tidak perbedaan bermakna dalam penilain recall test dan Clock Drawing Test.

Berdasarkan hasil penelitian pre test recall test yang bertujuan untuk menilai memori jangka pendek dengan menyebutkan 9 kata yang telah didengar dan dihafalkan sebelummnya pada kelompok intervensi sebesar 5.8 didapatkan nilai maksimum 9 yaitu terdiri dari 2 responden, yang mana responden tersebut mampu menyebutkan 9 kata dengan benar. Nilai minimum 4 yaitu terdapat 7 responden, dimana responden tersebut hanya mampu menyebutkan 4 kata dengan benar. Responden yang mendapatkan nilai minimum yaitu dengan usia 65 tahun ke atas dan lansia dengan latar belakang pendidikan SD. Dan setelah dilakukan tindakan nilai rata -rata penilaian recall test post test mengalami kenaikan menjadi 8.0 dengan nilai maksimum 9 sebanyak 7 responden dan nilai minimum 5 sebanyak 1 responden. Coresa, T. (2014), menyebutkan bahwa proses menua sehat (normal aging) secara fisiologi yaitu terjadi kemunduran beberapa aspek kognitif seperti kemunduran daya ingat terutama memori kerja (working memory) yang amat berperan dalam aktifitas hidup sehari- hari, hal ini menjelaskan mengapa pada sebagian lanjut usia menjadi pelupa. Selain itu fungsi belahan otak sisi kanan sebagai pusat intelegensi dasar akan mengalami kemunduran lebih cepat dari pada belahan otak sisi kiri sebagai pusat inteligensi kristal yang memantau pengetahuan. Dampak dari kemunduran belahan otak sisi kanan pada lanjut usia antara lain adalah kemunduran fungsi kewaspadaan dan perhatian (Coresa, T., 2014).

Adapun pemeriksaan lain yang dilakukan yaitu clock drawing test, pemeriksaan ini bertujuan untuk melakukan penilaian memori tentang orientasi waktu yaitu penggambaran jam, hasil penilaian kelompok intervensi pada pre test sebesar 2.5 dengan nilai maksimum 1 dicapai oleh 3 responden, dimana responden tersebut mampu menggambar lingkaran dengan penuh dan mampu menulis jam 11 lebih 10 menit dengan benar. Dan nilai minimum 4 dicapai oleh 2 responden, dimana responden tersebut tidak mampu menuliskan angka 1-12 pada lingkaran secara lengkap dan jarak antar angka tidak akurat. Untuk kelompok post test nilai rata -rata sebesar 1.7 dengan nilai maksimun 1 dicapai oleh 6 orang, dimana responden tersebut mampu menggambar jam secara sempurna tidak ada kesalahan sama sekali dan nilai minimum 3 dicapai oleh 2 responden, responden yang mendapatkan nilai 3 tidak mampu menunjukkan setting pukul "11 lebih 10 menit" dan jarum yang menunjukkan menit berada pada angka 10. Hasil penelitian pada pengukuran clock drawing test ini sejalan dengan hasil penelitian Sri Hartati dan Costrie Ganes Widayanti tidak semua responden mampu menyelesaikannya dengan baik (Hartati, S. dan Widayanti, C. G., 2010). Beberapa faktor yang dapat mempengaruhi penurunan fungsi kognitif pada lansia diantaranya proses penuaan pada otak dan 
pertambahan usia. Setiap tahun ditemukan terjadinya pengurangan volume pada masingmasing area seperti lobus frontalis $(0,55 \%)$, dan lobus temporal $(0,28 \%)$. Pengurangan volume otak juga akan disertai dengan penurunan kognitif. Bertambahnya usia seseorang maka akan semakin banyak terjadi perubahan pada berbagai sistem dalam tubuh yang cenderung mengarah pada penurunan fungsi diantaranya penurunan kemampuan fungsi intelektual, berkurangnya kemampuan transmisi saraf di otak yang menyebabkan proses informasi menjadi lambat, banyak informasi hilang selama transmisi, berkurangnya kemampuan mengakumulasi informasi baru dan mengambil informasi dari memori (Ningsih, M.A.D, 2016).

Penelitian yang sama juga dilakukan pada kelompok kontrol dengan tujuan untuk mengetahui adanya perbedaan perubahan yang terjadi pada kelompok intervensi yang dilakukan training memory. Berdasarkan hasil penelitian nilai rata - rata dari penilaian recall test kelompok kontrol pre test sebesar 4.8 dengan nilai maksimum 8 sebanyak 1 responden, dimana responden ini mampu menyebutkan 8 kata yang telah didengar dan dihafalkan sebelumnya dan nilai minimum 4 sebanyak 9 orang, dimana responden hanya mampu menyebutkan 4 kata saja dan menyebutkan dengan lambat, nilai rata -rata penilaian recall test post test sebesar 4.9 dengan nilai maksimum 8 sebanyak 1 responden dan nilai minimum sebanyak 9 responden. Berdasarkan hasil post test tidak ada perbedaan yang terjadi pada kelompok kontrol. Sedangkan penilaian clock drawing test kelompok kontrol pada pre test sebesar 2.8 dengan nilai maksimum 2 dicapai oleh 4 responden. Responden yang mendapatkan nilai 2 ini menggambar angka jam diluar lingkaran dan membalikkan kertas ketika menuliskan angka sehingga angka yang ditulis menjadi terbalik. Sedangkan nilai minimum 4 dicapai 2 responden, dimana responden ini tidak mampu menuliskan angka secara lengkap, menuliskan angka lebih dari 12, pembuatan jarak angka yang tidak akurat. Nilai rata - rata post test yaitu 2.6 dengan nilai maksimum 2 terdapat 6 responden dan nilai minimum 4 terdapat 2 responden. Artinya tidak ada perbedaan antara pre test dan post test pada kelompok kontrol tersebut.

Upaya untuk meningkatkan fungsi kognitif (memori) lansia bisa dilakukan dengan memberikan tindakan farmakologi dan non farmakologi yaitu dengan memory training. Memory training merupakan implementasi dalam meningkatkan kemampuan memory dengan teknik mnemonic. Tehnik Mnemonic yaitu suatu tehnik yang dipelajari yang mempunyai tujuan dalam membantu kinerja dari memory (ingatan) yang dapat dioptimalkan dengan latihan. Materi yang dapat digunakan didalam memory training yaitu tentang orientasi waktu dan menghafal 9 kata dengan cepat (re call) (Acevedo, A. dan Loewenstein, D. A., 2007). Tindakan non farmakologi ini berupa latihan atau permainan yang prosedurnya membutuhkan konsentrasi atau atensi, orientasi (tempat, waktu, dan situasi) dan memori. Kenaikan nilai pada masing-masing responden berbeda karena hasilnya tergantung kemampuan individu masing-masing. Memory training ini dilakukan 2 minggu sebanyak 6 kali. Dilakukannya training secara berulang-ulang ini bertujuan untuk memperkuat ingatan dan informasi guna untuk meningkatkan nilai pemeriksaan recall dan test drawing. Penyampaian mnemonic mempunyai kesan tersendiri bagi responden sehingga mampu memaknai materi yang disampaikan dengan baik. Adapun faktor yang berpengaruh terhadap kenaikan nilai pada masing-masing responden adalah faktor menyimak/ mendengarkan dengan baik sehingga memungkinkan informasi yang disampaikan oleh peneliti dapat dicerna responden dengan baik.

Berdasarkan uji Wilcoxon didapatkan nilai Recall Test pada kelompok intervensi $\mathrm{p}$ $=0.001$ atau $\mathrm{p} \leq 0.05$ yang berarti $\mathrm{H} 1$ diterima yaitu terdapat perbedaan sebelum dan sesudah diberikan Tindakan memory training. Penilaian Clock Drawinng test pada kelompok intervensi dengan nilai $\mathrm{p}=0.003$ atau $\mathrm{p} \leq 0.05$ yang berarti $\mathrm{H} 1$ diterima yaitu 
adanya perbedaan sebelum dan sesudah diberikannya Tindakan memory training. Hasil penelitian ini menunjukkan bahwa intervensi Memory Training dapat meningkatkan kognitif pada lansia. Hasil penelitian ini sejalan dengan hasil penelitian Hidayati, N., Haryanto, J. dan Makhfudli, M. (2014), bahwa hasil uji independent t-test menunjukkan nilai $p=0.031$ pada clock drawing test dan $p=0.018$ pada recall test. Nilai $p \leq 0.05$, hal ini berarti bahwa adanya pengaruh memory training terhadap kemampuan memori jangka pendek pada Lansia di UPTD Griya Wreda Surabaya (Hidayati, N., Haryanto, J. dan Makhfudli, M., 2014). Uji Wilcoxon pada kelompok kontrol menunjukkan nilai Recall Test diperoleh nilai 0.317 dan pada Clock Drawing Test diperoleh nilai 0.083, data penilaian ini menunjukkan bahwa $\mathrm{p}>0.05$ yang berarti bahwa tidak perbedaan bermakna dalam penilain recall test dan Clock Drawing Test. Sehingga secara garis besar dapat diketahui responden pada kelompok intervensi dengan dilakukan implementasi memory training mempunyai kognitif memori jangka pendek yang lebih baik dibandingkan kelompok kontrol.

\section{SIMPULAN DAN SARAN Simpulan}

Ada peningkatan dari rata - rata dari penilaian recall test kelompok intervensi pre test 5.8 dan nilai rata -rata penilaian recall test post test sebesar 8.0, Ada peningkatan penilaian clock drawing test kelompok intervensi pada pre test sebesar 2.5 dan kelompok post test nilai rata -rata sebesar 1.7. Hasil uji Wilcoxon menunjukkan nilai Recall Test pada kelompok intervensi $p$ value 0.001 atau $\mathrm{p} \leq 0.05$ yang berarti $\mathrm{H} 1$ diterima yaitu terdapat perbedaan sebelum dan sesudah diberikan Tindakan memory training. Penilaian Clock Drawinng test pada kelompok intervensi dengan nilai $\mathrm{p}$ value 0.003 atau $\mathrm{p} \leq 0.05$ yang berarti $\mathrm{H} 1$ diterima yaitu adanya perbedaan sebelum dan sesudah diberikannya Tindakan memory training. Memory training dapat meningkatkan fungsi kognitif pada lansia.

\section{Saran}

Kegiatan memory training dapat dimasukkan ke dalam program rutin rumah pelayanan sosial lanjut usia Margo Mukti Rembang untuk meningkatkan fungsi kognitif lansia serta lansia diharapkan dapat menerapkan cara mengingat dengan teknik mnemonic dalam keseharianya agar fungsi kognitif nya terjaga bahkan meningkat.

\section{UCAPAN TERIMAKASIH}

Peneliti menyampaikan terimakasih yang sebesar-besarnya kepada Kemenristek/BRIN, LLDIKTI wilayah VI Jawa Tengah, Rumah pelayanan sosial lanjut usia Margo Mukti Rembang, Akademi Keperawatan Krida Husada atas kesempatan yang berikan sehingga penelitian Implementasi Peningkatan kognitif Lansia melalui Memory Training bisa terlaksana dengan baik.

\section{DAFTAR PUSTAKA}

Abraham, C. dan Shanley, E. (1997), Psikologi Sosial untuk Perawat, Jakarta: EGC

Acevedo, A, dan Loewenstein, D, A. (2007), 'Nonpharmacological cognitive interventions in aging and dementia,'Journal of Geriatric Psychiatry and Neurology, vol.20,

Badan Pusat Statistik (2010). Data Statistik Indonesia: Jumlah Penduduk Menurut Kelompok Umur, Jenis Kelamin, Provinsi, dan Kabupaten/ Kota. 
Coresa, T. dan Ngestiningsih, D. (2017). Gambaran Fungsi Kognitif Pada Lansia Di Unit Rehabilitasi Sosial Pucang Gading Semarang. DIPONEGORO MEDICAL JOURNAL (JURNAL KEDOKTERAN DIPONEGORO), 6(1), 114-119.

Dahlan, M. S. (2011). Statistik untuk kedokteran dan Kesehatan: deskriptif, bivariat,dan multivariat, dilengkapi dengan menggunakan SPSS. Jakarta: Salemba Medika

Hartati, S. dan Widayanti, C. G. (2010). Clock drawing: Asesmen untuk demensia (Studi deskriptif pada orang lanjut usia di kota Semarang). Jurnal Psikologi, 7(1), 1-10.

Hidayati, N., Haryanto, J. dan Makhfudli, M. (2014). Memory training meningkatkan memori jangka pendek lansia. Indonesian Journal of Community Health Nursing, 3(1).

Ogawa, Masayo, et al. (2018). Analysis Of Risk Factors For Mild Cognitive Impairment Based On Word List Memory Test Results And Questionnaire Responses In Healthy Japanese Individuals Registered In An Online Database.doi.org/10.1371. https://journals.plos.org/plosone/article?id=10.1371/journal.pone.0197466. Diakses pada tanggal 12 Agustus 2019.

Santos, T., Lovell, J., Shiell, K., Johnson, M. dan Ibrahim, J. E. (2018). The impact of cognitive impairment in dementia on self-care domains in diabetes: A systematic search and narrative review. Diabetes/metabolism research and reviews, 34(6), e3013.

Solso, R.L., Maclin, O.H. dan Maclin, M.K. (2008), Psikologi Kognitif, Ed. 8, Jakarta:Penerbit Erlangga.

Sugiyono. (2010). Metode penelitian kuantitatif, kualitatif, dan $r \& d$. Bandung: Alfabeta

Triwibowo, H. dan Puspitasari, K. (2018). Hubungan Aktivitas Fisik dengan Fungsi Kognitif pada Lansia di Desa Tanjungan Kec. Kemlagi Kab. Mojokerto. Keperawatan, 3(2).

Turana, Y. (2014). Stop Pikun di Usia Muda. Jakarta: Gramedia Pustaka Utama.

US Cencus Bureau. (2018). Berapa Jumlah Penduduk Dunia.https://databoks.katadata.co.id/datapublish/2018/04/23/berapajumlahpendudukdunia. Diakses 12 Agustus 2019. 